\section{PERLINDUNGAN HUKUM TERHADAP HAK-HAK BUDAYA MASYARAKAT ADAT DALAM PERSPEKTIF HUKUM HAK ASASI MANUSIA ${ }^{1}$ Oleh: Zidane Tumbel ${ }^{2}$}

\begin{abstract}
ABSTRAK
Tujuan dilakukannya penelitian ini adalah untuk mengetahui bagaimana Pengaturan Hukum Hak Budaya Masyarakat Adat Menurut Konvensi Internasional Dibidang Hak Asasi Manusia dan bagaimana Implementasi Jaminan Hukum Perlindungan Hak Budaya Masyarakat Adat Dalam Hukum Nasional. Dengan menggunakan metode penelitian yuridis normatif, disimpulkan: 1. Hak masyarakat adat telah diatur dalam beberapa Konvensi Internasional dibidang Hak Asasi Manusia, yakni, Deklarasi Universal Hak Asasi Mnusia) 1948 (DUHAM), ICESCR (Hak-hak ekonomi, sosial dan budaya) diakui dan dilindungi oleh instrumen-instrumen hak asasi manusia internasional dan regional, yakni; Convention of International Labor Organization Concerning Indigeneous and Tribal
\end{abstract} People in Independent Countries (1989), Deklarasi Cari- Oca tentang Hak-Hak Masyarakat Adat (1992), Deklarasi Bumi Rio de Janairo (1992), Declaration on the Right of Asian Indigenous Tribal People Chianmai (1993), De Vienna Declaration and Programme Action yang dirumuskan oleh United Nations World Conference on Human Rights (1993). Sekarang istilah indigenous people semakin resmi penggunaannya dengan telah lahirnya Deklarasi PBB tentang Hak-Hak Masyarakat Adat (United Nation Declaration on the Rights of Indegenous People) pada tahun 2007 yang disingkat dengan UNDRIP. 2. Sebagai negara pihak dalam konvensi-konvensi HAM internasional yang berkaitan dengan hak masyarakat adat, Indonesia merupakan bagian yang tidak terpisahkan dari konsepsi HAM sebagaimana diakui, dihormati, dan dilindungi oleh negara dalam UUD 1945 Indonesia telah melakukan tindakan implementasi dalam hukum nasional dalam bentuk Peraturan Perundang-undangan yang berkaitan dengan HAM dan peraturan perundang-undangan lainnya, sebagaimana yang terdapat dalam Undang-Undang Dasar

\footnotetext{
${ }^{1}$ Artikel Skripsi. Dosen Pembimbing: Dr. Rudy H. Walukow, $\mathrm{SH}, \mathrm{MH}$; Dr. Diana R. Pangemanan, SH, MH

${ }^{2}$ Mahasiswa pada Fakultas Hukum Unsrat, NIM. 16071101663
}

Tahun 1945, Undang-Undang Nomor. 39 Tahun 1999 tentang Hak Asasi Manusia.

Kata kunci: Perlindungan Hukum, Hak-Hak Budaya Masyarakat Adat, Perspektif Hukum Hak Asasi Manusia

\section{PENDAHULUAN}

\section{A. Latar Belakang}

Hak asasi manusia (HAM) adalah hak-hak yang dimiliki manusia semata-mata karena ia manusia. Umat manusia memilikinya bukan karena diberikan kepadanya oleh masyarakat atau berdasarkan hukum positif, melainkan semata-mata berdasarkan martabatnya sebagai manusia. ${ }^{3}$ Dalam arti ini, maka meskipun setiap orang terlahir dengan ras, suku, jenis kelamin, bahasa, budaya, agama dan kewarganegaraan yang berbeda-beda, ia tetap mempunyai hakhak yang harus dijunjung tinggi oleh siapapun juga, dan di negara manapun ia berada. Inilah sifat universal dari HAM tersebut.

Perhatian masyarakat internasional terhadap hak asasi manusia (HAM) merupakan gejala yang relatif baru. Meskipun kita dapat menunjuk pada sejumlah traktat atau perjanjian internasional yang mempengaruhi isu kemanusiaan sebelum perang dunia II, baru setelah dimasukkan ke dalam Piagam Perserikatan Bangsa-Bangsa (PBB) pada Tahun 1945, kita dapat berbicara mengenai adanya perlindungan hak asasi manusia yang sistematis di dalam sistem internasional. ${ }^{4}$

Salah satu bagian dari hak asasi manusia adalah Hak Asasi Sosial Budaya, dalam hal ini hak masyarakat hukum adat, dimana setiap masyarakat memiliki hak untuk berinovasi dan berkreasi. Hak ini sudah diatur di dalam hak asasi manusia sehingga tidak akan ada yang bias dan yang melarang sesama warga dalam hal ini selama apa yang dilakukannya tidaklah menyalahi aturan dan tidak membuat warga lainnya menjadi rugi. Pemerintah bahkan juga tidak berwenang untuk membatasi apa yang ingin dilakukan oleh warganya, hak ini adalah hak istimewa karena kita dibebaskan berinovasi dan berkreasi.

\footnotetext{
3 Jack Donnely, Universal Human Rights in Theory and Practice, (London: Cornell UniversityPress,2003), hlm.21.

${ }^{4}$ Scott Davidson, Hak Asasi Manusia; Sejarah, Teori, dan Praktek dalam Pergaulan Internasional, Terjemahan dari Human Rights, Alih Bahasa: A. Hadyana Pudjaatmaka, (Jakarta: PT. Pustaka Utama Grafiti, 1994), hlm. 1
} 
Pengakuan terhadap hak masyarakat adat tersebut secara konstitusional diakui di dalam UUD 1945 pada Pasal 18B ayat (2) yang menyatakan : "Negara mengakui dan menghormati kesatuan-kesatuan masyarakat hukum adat beserta hak-hak tradisionalnya sepanjang masih hidup dan sesuai dengan perkembangan masyarakat dan prinsip Negara Kesatuan Republik Indonesia, yang diatur dalam undang-undang."

Secara faktual setiap provinsi di Indonesia terdapat kesatuan - kesatuan masyarakat hukum adat dengan karakteristiknya masing masing yang telah ada ratusan tahun yang lalu. Masyarakat hukum adat adalah kelompok masyarakat yang teratur, yang bertingkah laku sebagai kesatuan, menetap disuatu daerah tertentu, mempunyai penguasa-penguasa, memiliki hukum adat masing-masing dan mempunyai kekayaan sendiri baik berupa benda yang berwujud ataupun tidak berwujud serta menguasai sumber daya alam dalam jangkauannya. $^{5}$

Pasal 1 Undang-undang Nomor 39 Tahun 1999 tentang Hak Asasi Manusia, hak asasi manusia diartikan seperangkat hak yang melekat pada hakikat keberadaan manusia sebagai makhluk Tuhan Yang Maha Esa dan merupakan anugerah-Nya yang wajib dihormati dan dijunjung tinggi oleh negara, hukum, pemerintah, dan setiap orang demi kehormatan serta perlindungan harkat dan martabat manusia.

Berdasarkan uraian tersebut diatas, penulis tertarik menulis karya ilmiah dalam bentuk skripsi tentang "Jaminan Hukum Terhadap HakHak Budaya Masyarakat Adat Dalam Perspektif Hukum Hak Asasi manusia"

\section{B. Perumusan Masalah}

1. Bagaimanakah Pengaturan Hukum Hak Budaya Masyarakat Adat Menurut Konvensi Internasional Dibidang Hak Asasi Manusia

2. Bagaimanakah Implementasi Jaminan Hukum Perlindungan Hak Budaya Masyarakat Adat Dalam Hukum Nasional ?

\footnotetext{
${ }^{5}$ Taqwaddin, "Penguasaan Atas Pengelolaan Hutan Adat oleh Masyarakat Hukum Adat(Mukim) di Provinsi Aceh", (Disertasi Doktor Ilmu Hukum, Universitas Sumatera Utara, 2010),hlm.36.
}

\section{Metode Penelitian}

Secara umum, ruang lingkup penelitian ini merupakan disiplin ilmu hukum, yakni Hukum HAM, khususnya berkaitan dengan hak budaya masyarakat adat, yang tertuang dalam Konvensi HAM Internasional yang mengikat negaranegara dalam mengimplenetasikannya, maka penelitian ini merupakan bagian dari penelitian hukum yakni dengan cara meneliti bahan pustaka yang dinamakan penelitian hukum kepustakaan. ${ }^{6}$ Sedangkan metode pendekatan yang digunakan dalam penelitian ini adalah yuridis normatif, yaitu penelitian yang difokuskan untuk mengkaji penerapan kaidahkaidah atau norma-norma dalam hukum normatif. $^{7}$

\section{PEMBAHASAN}

\section{A. Pengaturan Hukum Hak Budaya Masyarakat Adat Menurut Konvensi Internasional Dibidang Hak Asasi Manusia}

Berkaitan dengan keberadaan masyarakat adat (indigeneous people), sudah dikenal luas dan telah disebutkan dalam sejumlah kesepakatan internasional, yaitu : Convention of International Labor Organization Concerning Indigeneous and Tribal People in Independent Countries (1989), Deklarasi Cari- Oca tentang Hak-Hak Masyarakat Adat (1992), Deklarasi Bumi Rio de Janairo (1992), Declaration on the Right of Asian Indigenous Tribal People Chianmai (1993), De Vienna Declaration and Programme Action yang dirumuskan oleh United Nations World Conference on Human Rights (1993). Sekarang istilah indigenous people semakin resmi penggunaannya dengan telah lahirnya Deklarasi PBB tentang Hak-Hak Masyarakat Adat (United Nation Declaration on the Rights of Indegenous People) pada tahun 2007 yang disingkat dengan UNDRIP.

Deklarasi ini merupakan dokumen hak asasi manusia yang komprehensif yang mengatur hak-hak dari masyarakat adat. Di dalamnya berisi mengenai standar minimal yang harus dipenuhi oleh setiap anggota PBB dalam menjamin hak yang dimiliki oleh indigenous

\footnotetext{
${ }^{6}$ Soerjono Soekanto dan Sri Mamudji, Penelitian Hukum Normatif, Rajawali, Jakarta, 1985, hal. 14.

${ }^{7}$ Johnny Ibrahim, Teori dan Metodologi Penelitian Hukum Normatif, Bayu Media, Malang, 2008, hIm.306. 92
} 
peoples. Sebagai sebuah dokumen, UNDRIP diadopsi pada tahun 2007 oleh mayoritas di Majelis Umum PBB. Dengan demikian, UNDRIP merupakan sebuah konsensus global.

Konstitusi-konstitusi modern di dunia, ditandai, salah satunya oleh penegasan atau pengaturan jaminan perlindungan hak-hak asasi manusia. Konstitusi-konstitusi yang mengadopsi prinsip-prinsip hak-hak asasi manusia, setidaknya telah mendorong pada suatu idealitas sistem politik (ketatanegaraan) yang bertanggung jawab pada rakyatnya, karena menegaskannya dalam hukum dasar atau tertinggi di suatu negara. Di sinilah sesungguhnya konteks relasi negara-rakyat diuji, tidak hanya dalam bentuknya yang termaterialkan dalam konstitusi sebuah negara, tetapi bagaimana negara mengimplementasikan tanggung jawabnya atas penghormatan, perlindungan, dan pemenuhan hakhak asasi manusia. $^{8}$

Dalam dunia internasional hak-hak masyarakat hukum adat juga telah mendapatkan pengakuan. Deklarasi Perserikatan Bangsa-Bangsa (PBB) tahun 2007 tentang Hak-Hak Masyarakat Hukum Adat menyatakan bahwa pengakuan atas hak-hak masyarakat adat akan bermanfaat meningkatkan keharmonisan dan hubungan kerjasama antara negara dan masyarakat adat, yang didasarkan pada prinsip-prinsip keadilan, demokrasi, penghormatan terhadap Hak Asasi Manusia, tanpa diskriminasi dan dapat dipercaya. ${ }^{9}$

Berpedomankan pada tujuan-tujuan dan prinsip- prinsip Piagam PBB, serta keyakinan yang kuat atas terpenuhinya kewajibankewajiban yang ditanggung oleh Negara-Negara sesuai dengan Piagam. Menegaskan bahwa masyarakat adat sejajar dengan semua masyarakat lainnya, sementara tetap mengakui

\footnotetext{
${ }^{8}$ R. Herlambang Perdana Wiratraman, Konstitusionalisme \& Hak-Hak Asasi Manusia (Konsepsi Tanggung Jawab Negara Dalam Sistem Ketatanegaraan Indonesia), Jurnal IImu Hukum Yuridika Vol. 20, No. I, Januari 2005. HIm. 2.

${ }^{9}$ I Nyoman Budiana, 26 April 2014, Hak Masyarakat Hukum Adat dan Peran Serta Desa Adat Dalam Perlindungan Masyarakat Adatnya, (disampaikan Dalam Seminar Dewan Perwakilan Daerah RI dalam Kajian Hukum Adat Bali di Tengah Modernisasi Pembangunan dan Arus Budaya Global, di Kampus Mahasaraswati Denpasar), $\mathrm{hlm} .2$
}

hak semua orang untuk berbeda, untuk memandang dirinya berbeda, dan untuk dihargai karena perbedaan tersebut. Menegaskan kembali bahwa masyarakat adat, dalam melaksanakan hak-haknya, harus bebas dari segala bentuk diskriminasi, apa pun jenisnya.

Deklarasi PBB tentang Hak-Hak Penduduk Asli adalah sebuah deklarasi yang disahkan Majelis Umum Perserikatan Bangsa-Bangsa (MU PBB) dalam sesi ke-61-nya di Markas PBB di New York, 13 September 2007. Deklarasi ini menggariskan hak individual dan kolektif para penduduk asli (pribumi), dan juga hak mereka terhadap budaya, identitas, bahasa, pekerjaan, kesehatan, pendidikan dan isu-isu lainnya.

Deklarasi ini juga menekankan hak mereka untuk memelihara dan memperkuat institusi, budaya dan tradisi mereka, dan hak mereka akan pembangunan untuk memenuhi kebutuhan dan aspirasi mereka. Deklarasi ini juga melarang diskriminasi terhadap penduduk asli, dan memajukan partisipasi mereka secara penuh dan efektif dalam segala hal yang menyangkut masalah mereka, serta hak mereka untuk tetap berbeda, dan mengusahakan visi pembangunan ekonomi dan sosial mereka sendiri. ${ }^{10}$

Walaupun deklarasi ini tidak mengikat secara hukum, sebagaimana juga DeklarasiDeklarasi Majelis Umum lainnya, deklarasi ini menggambarkan perkembangan dinamis dari norma hukum internasional, dan merefleksikan komitmen dari negara-negara anggota PBB untuk bergerak ke arah tertentu; PBB menggambarkannya sebagai memberikan standar penting bagi perlakuan terhadap penduduk-penduduk asli di seluruh dunia, yang tentu saja akan menjadi alat yang penting dalam memberantas pelanggaran HAM terhadap 370 juta penduduk asli di dunia, dan membantu mereka memerangi diskriminasi dan marjinalisasi.

Deklarasi PBB tentang Hak-Hak Masyarakat Adat (United Nation Declaration on the Rights of Indegenous People-UNDRIP) pada tahun 2007, Menurut Pasal. 1, bahwa : Masyarakat adat mempunyai hak terhadap penikmatan penuh, untuk secara bersamasama atau secara sendiri-sendiri, semua hak

\footnotetext{
${ }^{10}$ referensi.elsam.or.id/2014/10/deklarasi-pbb-tentang-
} hak-hak-masyarakat-adat/Elsam, diakses, November 2019 
asasi manusia dan kebebasan-kebebasan dasar yang diakui dalam Piagam Perserikatan Bangsa-Bangsa, Deklarasi Universal Hak-Hak Asasi Manusia dan hukum internasional tentang hak asasi manusia.

Selanjutnya Pasal 2 menyebutkan bahwa : Masyarakat adat dan warga-warganya bebas dan sederajat dengan semua kelompokkelompok masyarakat dan warga-warga lainnya, dan mempunyai hak untuk bebas dari segala bentuk diskriminasi dalam menjalankan hak-hak mereka, khususnya yang didasarkan atas asal-usul atau identitas mereka.

Pasal 11:

1. Masyarakat adat mempunyai hak untuk mempraktikkan dan memperbarui tradisitradisi dan adat budaya mereka. Hal ini meliputi hak untuk mempertahankan, melindungi dan mengembangkan wujud kebudayaan mereka di masa lalu, sekarang dan yang akan datang, seperti situs-situs arkeologi dan sejarah, artefak, disain, upacara-uparaca, teknologi, seni visual dan seni pertunjukan dan kesusasteraan.

2. Negara-negara akan melakukan pemulihan melalui mekanisme yang efektif termasuk restitusi, yang dibangun dalam hubungannya dengan masyarakat adat, dengan rasa hormat pada kekayaan budaya, intelektual, religi dan spiritual mereka, yang telah diambil tanpa persetujuan bebas dan sadar dari mereka, atau yang melanggar hukum-hukum, tradisi dan adat mereka.

Pasal 12 :

1. Masyarakat adat mempunyai hak untuk mewujudkan, mempraktikkan, mengembangkan dan mengajarkan tradisi, kebiasaan dan upacara spiritual dan religi mereka; hak untuk mempertahankan, melindungi, dan mempunyai akses dengan keleluasaan pribadi terhadap situs-situs religi dan kultural mereka; hak akan penggunaan dan kontrol terhadap objekobjek seremonial mereka; dan hak akan repatriasi jasad manusia mereka.

2. Negara-negara akan mencari akses yang memungkinkan dan/atau mengembalikan objek-objek upacara dan tempat-tempat pemakaman kepada mereka melalui mekanisme yang transparan dan efektif, yang dibangun dalam hubungannya dengan apa yang menjadi perhatian masyarakat adat yang bersangkutan.

\section{B. Implementasi Jaminan Hukum \\ Perlindungan Hak Budaya Masyarakat Adat Dalam Hukum Nasional}

Sebagai wujud adanya jaminan perlindungan terhadap masyarakat adat di Indonesia, hal ini dapat dilihat dalam beberapa peraturan perundang-undangan yang mengakomodir masyarakat hukum adat, yaitu :

\section{a. Undang-Undang Dasar Negara Republik Indonesia 1945}

Sebagai negara yang menganut tradisi Civil Law System, maka dalam membaca sistem hukum Indonesia haruslah berangkat dari hierarkhi perundang-undangan yang paling tinggi tingkatannya yakni UUD 1945. Begitu pula dalam mengelaborasi pengaturan mengenai eksistensi masyarakat adat dalam sistem politik hukum Indonesia, hal yang paling mudah adalah dengan pertama kali mengkaji pengaturannya dalam UUD 1945.

Pasal 18 B ayat (2) Undang-Undang Dasar Negara Republik Indonesia 1945 mengemukakan bahwa "Negara mengakui dan menghormati kesatuan-kesatuan masyarakat hukum adat serta hak-hak tradisonalnya sepanjang masih hidup dan sesuai dengan perkembangan masyarakat dan prinsip Negara Kesatuan Republik Indonesia, yang diatur dalam undang-undang", juga ditegaskan pada Pasal 28 I ayat (3) UndangUndang Dasar Negara Republik Indonesia 1945 yang menyebutkan bahwa "Identitas budaya dan hak masyarakat tradisional dihormati selaras dengan perkembangan zaman dan peradaban."

\section{b. Undang-Undang Nomor 5 Tahun 1960 Tentang Pokok-Pokok Agraria (UUPA)}

Pasal 3 UUPA menentukan bahwa pelaksanaan hak ulayat dan hak-hak yang serupa dengan itu dari masyarakatmasyarakat hukum adat, sepanjang menurut kenyataannya masih ada, harus sedemikian rupa sehingga sesuai dengan kepentingan nasional dan negara, yang berdasarkan atas persatuan bangsa serta tidak boleh bertentangan dengan undang-undang dan 
peraturan-peraturan lain yang lebih tinggi. Pengertian terhadap istilah hak ulayat ditegaskan oleh G. Kertasapoetra dan kawankawan dalam bukunya Hukum Tanah, Jaminan UUPA Bagi Keberhasilan Pendayagunaan Tanah, menyatakan bahwa Hak Ulayat merupakan hak tertinggi atas tanah yang dimiliki oleh sesuatu persekutuan hukum (desa, suku) untuk menjamin ketertiban pemanfaatan/pendayagunaan tanah. Hak ulayat adalah hak yang dimiliki oleh suatu persekutuan hukum (desa, suku), dimana para warga masyarakat (persekutuan hukum) tersebut mempunyai hak untuk menguasai tanah, yang pelaksanaannya diatur oleh ketua persekutuan (kepala suku/kepala desa yang bersangkutan)". ${ }^{11}$

c. Undang-Undang Nomor 5 tahun 1990 tentang Konservasi Sumberdaya Alam Hayati dan Ekosistemnya (UU KSDAHE).

UU KSDAHE ini pada dasarnya meletakkan peran pemerintah sangat besar dalam kegiatan-kegiatan konservasi sumberdaya alam hayati dan ekosistem. Dengan besarnya peran pemerintah itu maka ruang bagi masyarakat hukum adat melakukan kegiatan konservasi sumberdaya alam hampir tidak ada. Undang-Undang ini tidak menyebutkan sedikit pun pengaturan tentang masyarakat hukum adat, meskipun mayarakat hukum adat di berbagai tempat mempunyai pranata, pengetahuan dan pengalaman konservasi sumberdaya alam.

\section{d. Undang-Undang Nomor 39 Tahun 1999 Tentang Hak Asasi Manusia (HAM)}

Undang-Undang HAM secara tegas menyatakan keberadaan masyarakat hukum adat dalam Pasal 6 ayat (1): "Dalam rangka penegakan hak asasi manusia, perbedaan dan kebutuhan dalam masyarakat hukum adat harus diperhatikan dan dilindungi oleh hukum, masyarakat, dan pemerintah." Di lihat dari perspektif HAM dan juga dari konstitusi Indonesia, tanggung jawab negara yang diwakili oleh pemerintah adalah mengakui,

\footnotetext{
${ }^{11}$ G.Kertasapoetra, R.G Kartasapoetra, AG.Kartasapoetra, A. Setiady, Hukum Tanah, Jaminan Undang- Undang Pokok Agraria Bagi Keberhasilan Pendayagunaan Tanah, (Jakarta: Bina aksara, 1985), hal. 88
}

menghormati, melindungi, dan memenuhi hak-hak dan masyarakat adat.

\section{e. Undang-Undang Nomor 41 Tahun 1999 Tentang Kehutanan}

Penjelasan Pasal 67 ayat (1) UU Kehutanan menyatakan bahwa masyarakat hukum adat, diakui keberadaannya jika menurut kenyataannya memenuhi unsur-unsur sebagai berikut: masyarakatnya masih dalam bentuk paguyuban (rechsgemeenschap); ada kelembagaan dalam bentuk perangkat penguasa adatnya; ada wilayah hukum adat yang jelas; ada pranata dan perangkat hukum, khususnya peradilan adat yang masih ditaati; masih mengadakan pemungutan hasil hutan di wilayah hutan sekitarnya untuk pemenuhan kebutuhan hidup sehari-hari. Salah satu hak masyarakat hukum adat yang erat kaitannya dengan UU ini adalah pengelolaan hutan adat.

\section{f. Undang-Undang Nomor 24 Tahun 2003 Tentang Mahkamah Konstitusi (UU MK)}

Pasal 51 ayat (1) UU MK menyebutkan bahwa salah satu kategori pemohon adalah "kesatuan masyarakat hukum adat sepanjang masih hidup dan sesuai dengan perkembangan masyarakat dan prinsip Negara Kesatuan Republik Indonesia yang diatur dalam undang-undang".

Pasal 24 C ayat (1) UUD 1945 memberikan wewenang pengujian Undang-Undang terhadap Undang-Undang Dasar kepada Mahkamah Konstitusi. Selanjutnya pasal 51 Undang-Undang Nomor 23 Tahun 2004 tentang Mahkamah Konstitusi antara lain menentukan bahwa "kesatuan masyarakat hukum adat" dapat menjadi pemohon apabila hak-hak konstitusionalnya dilanggar atau dirugikan oleh berlakunya suatu undangundang, tetapi harus memenuhi syarat kedudukan hukum (legal standing) yang ditentukan.

\section{g. Undang-Undang Nomor 23 Tahun 2014 Tentang Pemerintahan Daerah (UU Pemda) \\ UU Pemda pada dasarnya secara tegas telah memberikan kewenangan untuk Komunitas Masyarakat Hukum Adat untuk mengatur dan mengurus pemerintahan}


adatnya. ${ }^{12}$ Pada Pasal 1 angka 12 daerah Otonom yang dimaksud disebut sebagai kesatuan masyarakat hukum adat yang mempunyai batas-batas wilayah, berwenang mengatur dan mengurus pemerintahan dan kepentingan masyarakat setempat, menurut prakarsa sendiri berdasarkan aspirasi masyarakat dalam sistem Negara Kesatuan Republik Indonesia.

h. Undang-Undang Nomor 11 Tahun 2005 Tentang Pengesahan Kovenan Internasional Tentang Hak Ekonomi, Sosial, dan Budaya Undang-undang yang meratifikasi Kovenan Internasional tentang Hak Ekonomi, Sosial, dan Budaya ini antara lain mengakui secara umum hak-hak yang dimiliki oleh masyarakat hukum adat, yaitu hak untuk tidak didiskriminasi. sebagaimana diatur dalam Pasal 2 ayat (2), Pasal 2 ayat (3) dan Pasal 3. Hak atas kebudayaan dan hak untuk berpartisipasi diatur dalam Pasal 15, hak atas lingkungan yang sehat diatur dalam Pasal 12 . Hak atas kebudayaan merupakan salah satu hak yang penting yang dimiliki oleh kesatuan masyarakat hukum adat di Indonesia.

i. Undang-Undang Nomor 12 Tahun 2005 tentang Pengesahan Kovenan Internasional Tentang Hak Sipil dan Politik

Undang-undang yang meratifikasi Kovenan Internasional tentang Hak Sipil dan Politik ini secara tegas mengakui hak untuk tidak didiskriminasi bagi setiap orang sebagaimana diatur dalam Pasal 2 ayat (1) dan Pasal 3. Hak untuk menikmati seluruh hak, termasuk hak atas tanah dan sumberdaya alam diatur dalam Pasal 26, hak untuk menikmati cara hidup yang khas yang berhubungan dengan penggunaan tanah dan sumberdaya alam diatur dalam Pasal 27, serta hak untuk berpartisipasi yang diatur dalam Pasal 25.

\section{j. Undang-Undang Nomor 40 Tahun 2008 Tentang Penghapusan Diskriminasi Ras dan Etnis}

Pada prinsipnya undang-undang ini mengakui bahwa setiap warga negara berhak memperoleh perlakuan yang sama untuk

\footnotetext{
${ }^{12}$ AMAN, Otonomi Daerah Bagi Masyarakat Adat, Oktober 2015, Diakses melalui http://gaung.aman.or.id/2015/10/15/otonomi-daerahbagi-masyarakat-adat/ pada 21 Juli 2017
}

mendapatkan hak-hak sipil, politik, ekonomi, sosial dan budaya sesuai dengan ketentuan peraturan perundang-undangan, tanpa pembedaan ras dan etnis (Pasal 9). Maka berdasarkan UU ini, segala bentuk hak yang diatur dalam peraturan perundang-undangan di Indonesia harus diberikan termasuk serangkaian hak yang diletakkan kepada masyarakat hukum adat.

\section{k. Undang-Undang Nomor UU No. 2 Tahun 2001 tentang Minyak dan Gas Bumi (UU Migas)}

UU ini mengatur mengenai perlindungan terhadap masyarakat adat, seperti yang terdapat di dalam Pasal 11, Pasal 33 dan Pasal 34 UU Migas. Misal di dalam Pasal 11 UU Migas yang mengatur mengenai Kontrak Kerja Sama (KKS) dalam usaha hulu migas ditentukan bahwa di dalam KKS tersebut harus membuat beberapa ketentuan pokok, salah satunya adalah mengenai pengembangan masyarakat sekitarnya dan jaminan hak-hak masyarakat adat.

\section{Undang-Undang Nomor 32 Tahun 2009 Tentang Perlindungan dan Pengelolaan Lingkungan Hidup (PPLH)}

Pasal 63 ayat (1) huruf t, Pasal 63 ayat (2) huruf $n$, dan Pasal 63 ayat (3) huruf $k$ undangundang ini menentukan bahwa dalam perlindungan dan pengelolaan lingkungan hidup, Pemerintah dan Pemerintah Daerah bertugas dan berwenang menetapkan dan melaksanakan kebijakan mengenai tata cara pengakuan keberadaan masyarakat hukum adat, kearifan lokal, dan masyarakat hukum adat yang terkait dengan perlindungan dan pengelolaan lingkungan hidup. Selain itu, bahwa salah satu asa PPLH adalah kearifan lokal.

m. Undang-Undang No. 11 Tahun 2013 tentang Pengesahan Protokol Nagoya UU NO. 11 tahun 2013 tentang Pengesahan Protocol Nagoya.

Kebijakan ini membuka peluang untuk pengaturan pemanfaatan pengetahuan tradisional yang dimiliki masyarakat hukum adat secara adil dan seimbang. Namun berbagai isu penting diperkirakan akan mewarnai implementasi Protokol Nagoya, seperti: (1) 
Kapasitas dalam melaksanakan persetujuan atas dasar informasi awal tanpa paksaan dan kesepakatan bersama; (2) Kesulitan yang dihadapi menentukan kelompok masyarakat mana yang paling berhak untuk menerima pembagian keuntungan dari pemanfaatan pengetahuan tradisional; (3) Penetapan kelembagaan adat representasi masyarakat hukum adat.

\section{n. Undang-Undang No. 6 Tahun 2014 tentang Desa (UU Desa)}

Melalui UU Desa dimungkinkan perubahan: Desa menjadi Desa Adat, Kelurahan menjadi Desa, Kelurahan menjadi Desa Adat, Desa Adat menjadi Kelurahan. Desa/ Desa Adat dapat berubah status, digabung atau dihapus, berdasarkan prakarsa masyarakat dan ditetapkan dalam Perda (Provinsi atau Kabupaten/Kota) yang disertai peta wilayah. Lebih lanjut, hal penting yang juga harus dilihat dalam UU ini terkait kewenangan desa adat. Kewenangan berdasarkan hak asal usul adalah hak yang merupakan warisan yang masih hidup dan prakarsa Desa atau prakarsa masyarakat Desa sesuai dengan perkembangan kehidupan masyarakat. Khusus kewenangan asal-usul dalam Desa Adat, Pasal 103 UU Desa menegaskan sebagai berikut:

1. Pengaturan dan pelaksanaan pemerintahan berdasarkan susunan asli;

2. Pengaturan dan pengurusan ulayat atau wilayah adat;

3. Pelestarian nilai sosial budaya Desa Adat;

4. Penyelesaian sengketa adat berdasarkan hukum adat yang berlaku di Desa Adat dalam wilayah yang selaras dengan prinsip hak asasi manusia dengan mengutamakan penyelesaian secara musyawarah;

5. Penyelenggaraan sidang perdamaian peradilan Desa Adat sesuai dengan ketentuan peraturan perundangundangan;

6. Pemeliharaan ketenteraman dan ketertiban masyarakat Desa Adat berdasarkan hukum adat yang berlaku di Desa Adat; dan

7. Pengembangan kehidupan hukum adat sesuai dengan kondisi sosial budaya masyarakat Desa Adat.
Pendekatan administratif mengharuskan negara memberi ruang pada masyarakat adat untuk mengatur diri sendiri. Sementara pendekatan hak asasi manusia mengharuskan negara untuk mengambil langkah-langkah hukum untuk mencegah terjadinya pelanggaran terhadap masyarakat adat. Pendekatan hak asasi manusia juga mengharuskan negara untuk memajukan masyarakat adat. ${ }^{13}$

\section{o. Putusan MK Nomor 35/PUU-X/2012 atas uji materi UU No. 41/2009 tentang Kehutanan}

Keluarnya Putusan MK Nomor 35/PUUX/2012 atas uji materi UU No. 41/2009 tentang Kehutanan, dengan amar putusan antara lain bahwa Hutan adat adalah hutan yang berada dalam wilayah masyarakat hukum adat", memberi implikasi luas dalam upaya pengakuan keberadaan, kearifan lokal dan hak masyarakat hukum adat.

Meskipun terdapat berbagai permasalahan yang menghambat penerapan keputusan di atas, diantaranya karena ketidaktersediaan data dasar keberadaan masyarakat hukum adat dan kearifan lokal. Berdasarkan penjelasan di atas, saat ini sudah banyak undang-undang yang mengatur tentang keberadaan dan hak-hak masyarakat adat, terutama undang- undang di bidang sumber daya alam. Namun, alih-alih mengakui dan melindungi hak masyarakat adat, kebanyakan undang-undang tersebut malah 'merampas' hak masyarakat adat atas sumber-sumber kehidupan serta membatasi hak mereka. Undang-undang yang ada saat ini belum sepenuhnya berpihak kepada masyarakat adat. ${ }^{14}$ oleh karena itu, masyarakat adat memerlukan sebuah undang-undang kusus yang memberikan pengakuan dan perlindungan terhadap hakhak mereka.

\section{PENUTUP}

\section{A. Kesimpulan}

${ }^{13}$ AMAN, Mengapa Indonesia Memerlukan UU Pengakuan dan Perlindungan Hak Masyarakat Adat?, diakses melalui http://www.aman.or.id/wp-content/ uploads/2017/04/Mengapa-Indonesia-Memerlukan-UUMasyarakat-Adat.pdf pada 20 Agustus 2019, hlm 1 ${ }^{14}$ Ibid 
1. Hak masyarakat adat telah diatur dalam beberapa Konvensi Internasional dibidang Hak Asasi Manusia, yakni, Deklarasi Universal Hak Asasi Mnusia) 1948 (DUHAM), ICESCR (Hak-hak ekonomi, sosial dan budaya) diakui dan dilindungi oleh instrumen-instrumen hak asasi manusia internasional dan regional, yakni; Convention of International Labor Organization Concerning Indigeneous and Tribal People in Independent Countries (1989), Deklarasi Cari- Oca tentang HakHak Masyarakat Adat (1992), Deklarasi Bumi Rio de Janairo (1992), Declaration on the Right of Asian Indigenous Tribal People Chianmai (1993), De Vienna Declaration and Programme Action yang dirumuskan oleh United Nations World Conference on Human Rights (1993). Sekarang istilah indigenous people semakin resmi penggunaannya dengan telah lahirnya Deklarasi PBB tentang HakHak Masyarakat Adat (United Nation Declaration on the Rights of Indegenous People) pada tahun 2007 yang disingkat dengan UNDRIP.

2. Sebagai negara pihak dalam konvensikonvensi HAM internasional yang berkaitan dengan hak masyarakat adat, Indonesia merupakan bagian yang tidak terpisahkan dari konsepsi HAM sebagaimana diakui, dihormati, dan dilindungi oleh negara dalam UUD 1945 Indonesia telah melakukan tindakan implementasi dalam hukum nasional dalam bentuk Peraturan Perundangundangan yang berkaitan dengan HAM dan peraturan perundang-undangan lainnya, sebagaimana yang terdapat dalam Undang-Undang Dasar Tahun 1945, Undang-Undang Nomor. 39 Tahun 1999 tentang Hak Asasi Manusia.

\section{B. Saran}

1. Diperlukan kesadaran masyarakat internasional akan pentingnya perlindungan dan pemenuhan HAM berkaitan dengan hak masyarakat adat. Hal ini dikarenakan bahwa Paham yang terkandung dalam HAM memiliki sifat universalitas yang luar biasa dalam menghargai prinsip manusia sebagai makhluk social, oleh karena itu, negara sebagai pihak yang memangku tanggung jawab, semua negara dituntut harus melaksanakan dan memenuhi semua kewajiban internasional yang dikenakan kepadanya secara sekaligus dan segera.

2. Mengingat banyaknya instrumen hak asasi manusia internasional, maka dalam tahapan implementasinya di Indonesia diperlukan komitmen formal pemerintah pada persoalan pemenuhan dan perlindungannya agar dapat berjalan dengan baik. Karena setiap instrument internasional tentang HAM mendefinisikan tanggung jawab pemerintah/negara, dimana upaya meningkatkan perlindungan dan pemenuhan hak-hak masyarakat adat sebagai prioritas, meskipun secara normatif telah didukung landasan peraturan perundangan, namun dalam pelaksanaan masih belum memenuhi harapan.

\section{DAFTAR PUSTAKA}

Adolp Huala, Aspek-Aspek Negara dalam Hukum Internasional, Edisi Revisi, PT. RajaGrafindo Persada, Jakarta, 2002

Abdullah Rozali dan Syamsir, Perkembangan HAM dan Keberadaan Peradilan HAM di Indonesia, Jakarta: Ghalia Indonesia, 2002

Agus Fadillah, Pengantar Hukum Internasional dan Hukum Humaniter Internasional, Elsam, 2007, Jakarta

Alting Husen, Dinamika Hukum dalam Pengakuan dan Perlindungan Hak Masyarakat Hukum Adat Atas Tanah (Yogyakarta: LaksBang PRESSindo, 2010)

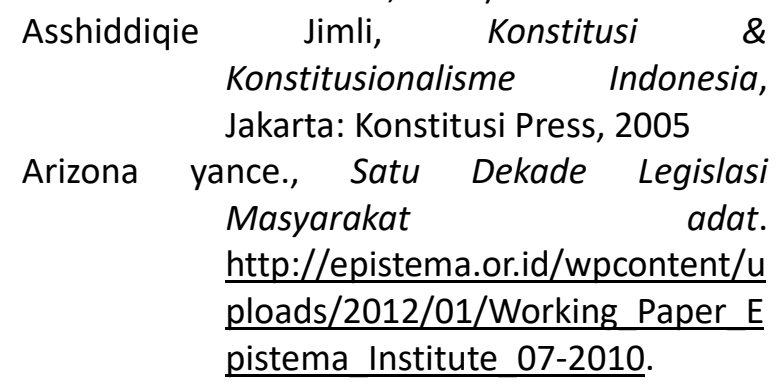

Bahar Safroedin, Seri Hak Masyarakat Hukum Adat: Inventarisasi dan Perlindungan Hak Masyarakat 
Hukum Adat, Jakarta: Komisi Nasional Hak Asasi Manusia, 2005.

Konteks Kenegaraan Hak Asasi Manusia, Pustaka Sinar Harapan, Jakarta, 2002

Bahagijo Sugeng dan Asmara Nababan, Hak Asasi Manusi: Tanggung Jawab Negara Peran Institusi Nasional dan Masyarakat, KOMNAS HAM, Jakarta, 1999.

Bushar Muhammad, Pokok-Pokok Hukum Adat (Jakarta: PT Pradnya Paramita, 1981)

Budiana I Nyoman, 26 April 2014, Hak Masyarakat Hukum Adat dan Peran Serta Desa Adat Dalam Perlindungan Masyarakat Adatnya, (disampaikan Dalam Seminar Dewan Perwakilan Daerah RI dalam Kajian Hukum Adat Bali di Tengah Modernisasi Pembangunan dan Arus Budaya Global, di Kampus Mahasaraswati Denpasar).

C De Rover., 2000, To Serve \& To Protect, Acuan Universal Penegakan HAM, PT Raja Grafindo Persada, Jakarta

Dardji Darmodiharjo dkk, Santiaji Pancasila, Usaha Nasional, Surabaya, 1981

Davidson Scott, Human Rights, (Hak Asasi Manusia : Sejarah Teori dan Praktek Dalam Pergaulan Internasional), Buckingham : Open University Press. 1993. Penterjemah, A. Hadyana Pudjaatmaka, Pustaka Utama Grafiti, Jakarta, 1994.

Djamanat Samosir. 2013. Hukum Adat Indonesia. Medan: CV. Nuansa Aulia

Donnely Jack,Universal Human Rights in Theory and Practice, (London: Cornell UniversityPress,2003)

Effendi Masyhur. Dimensi dan Dinamika Hak Asasi Manusia dalam Hukum Nasional dan Internasional, (Jakarta, Ghalia Indonesia, 1994)

Perkembangan Dimensi Hak asasi Manusia (HAM) \& proses dinamika penyusunan hukum hak asasi manusia, Ghalia utama, bogor, 2005
G.Kertasapoetra, R.G Kartasapoetra, AG.Kartasapoetra, A. Setiady, Hukum Tanah, JaminanUndangUndang Pokok Agraria Bagi Keberhasilan Pendayagunaan Tanah, (Jakarta: Bina aksara, 1985).

Hendry Dedek, 2015, Pengakuan Masyarakat Hukum Adat ; Hukum yang Memulai, Hukum juga yang harus Mengakhiri, diakses melalui http://www.akar.or.id/2015/10/22 /pengakuan-masyarakat-hukumadat-hukum-yang-memulaihukum-juga-yang-harusmengakhiri/, pada 20 Juli 2017

Irfan Nur Rahman, et.al., Dasar Pertimbangan Yuridis Kedudukan Hukum (Legal Standing) Kesatuan Masyarakat Hukum Adat dalam Proses Pengujian Undang-Undang di Mahkamah Konstitusi. (Jakarta: Pusat Penelitian dan Pengkajian Kepaniteraan dan Sekretariat Jendral Mahkamah Konstitusi Republik Indonesia, 2011)

Ibrahim Johnny, Teori dan Metodologi Penelitian Hukum Normatif, Bayu Media, Malang, 2008

Jayantha Perera, Land and Cultural Survival (The Communal Land Rights of Indigenous Peoples in Asia), ADB, 2009.

Koentjaraningrat, Sejarah Teori Antropologi II, Jakarta: UI - Press, 1990

Mauna Boer, 2001, Hukum Internasional; Pengertian, Peranan dan Fungsi Dalam Era Global, Edisi-1, cet. Ke2, Alumni, Bandung

Mawardi, implikasi hak kesatuan masyarakat hukum adat dalam pengelolaan tanah kawasan hutan di kabupaten Lombok Utara, Jurnal IUS Vol 1 Nomor 3 Desember 2013.

Majda El Muhtaj, Dimensi-Dimensi HAM Mengurai Hak Ekonomi, Sosial, dan

Budaya,(Jakarta:PT.GrafindoPersad a,2008)

Rover de C, To Serve \& To Protect Acuan Universal Penegakan HAM, PT.Raja Grafindo Persada, Jakarta, 2000 
R. Herlambang Perdana Wiratraman, Konstitusionalisme \& Hak-Hak Asasi Manusia (Konsepsi Tanggung Jawab Negara Dalam Sistem Ketatanegaraan Indonesia), Jurnal IImu Hukum Yuridika Vol. 20, No. I, Januari 2005.

Shaw, Malcolm N., International Law, London: Butterworths,1986.

Soerjono Soekanto. 2010. Hukum Adat Indonesia. Jakarta: Rajawali Pers.

Soerjono Soekanto dan Sri Mamudji, Penelitian Hukum Normatif, Rajawali, Jakarta, 1985

Taqwaddin, "Penguasaan Atas Pengelolaan Hutan Adat oleh Masyarakat Hukum Adat(Mukim) di Provinsi Aceh", (Disertasi Doktor IImu Hukum, Universitas Sumatera Utara, 2010)

Taqwaddin, "Penguasaan Atas Pengelolaan Hutan Adat oleh Masyarakat Hukum Adat(Mukim) di Provinsi Aceh", (Disertasi Doktor IImu Hukum, Universitas Sumatera Utara, 2010)

Widjaja. H.A.W. Penerapan Nilai-nilai Pancasila \& HAM Di Indonesia, PT. Rineka Cipta, Jakarta, 2000.

\section{Sumber lain :}

- UUD 1945

- UU No. 39 Tahun 1999 Tentang HAM

- UU No 11 tahun 2005 tentang Pengesahan Kovenan Hak Ekonomi, Sosial dan Budaya (ICESCR)

- DUHAM 1948

- Deklarasi PBB tentang Hak-Hak Masyarakat Adat (United Nation Declaration on the Rights of Indegenous People-UNDRIP)

- Konvensi Wina 1969. Ketentuan yang sama juga terdapat dalam UU No. 24 tahun 2000 tentang Perjanjian Internasional.

- Lembaga Bantuan Hukum Asosiasi Untuk Keadilan, 2001

Internet :

- http://manusia pinggiran.blogspot.com/2013/01/pengerti an-ham. Diakses, okt 2018

- Mahyuni, "Pengakuan Dan Penghormatan Negara Terhadap Masyarakat Adat Serta Hak-Hak Tradisionalnya di Provinsi
Kalimantan Selatan". Makalah. http://mahyunish.blogspot.com/2013/09/ makalah-pengakuan-dan-penghormatan.

- referensi.elsam.or.id/2014/10/deklarasipbb-tentang-hak-hak-masyarakatadat/Elsam, diakses, November 2019

- https://sopianhadi1983.wordpress.com/20 14/09/19/pengakuan-masyarakatadat/\#more137 (diakses pada tanggal 20 oktober 2019)

- Aliansi Masyarakat Adat Nusantara (AMAN),

http://gaung.aman.or.id/2016/12/14/indo nesia-memerlukan-uu-pengakuan-danperlindungan-hak-masyarakat-adat/ pada 20 Juli 2017.

- http://www.mahkamahkonstitusi.go.id/pu blic/content/infoumum/penelitian/pdf/Ma syarakat\%20Hukum\%20Adat.pdf pada 20 Juli 2017. 